American Journal of Environmental Sciences 6 (3): 249-252, 2010

ISSN 1553-345X

(C) 2010 Science Publications

\title{
Population Growth, Climate Change and Water Scarcity in the Southwestern United States
}

\author{
${ }^{1,2}$ Amy C. Fuller and ${ }^{2,3}$ Michael O. Harhay \\ ${ }^{1}$ Department of Earth and Environmental Science, University of Pennsylvania, \\ ${ }^{2}$ Graduate Program in Public Health Studies, University of Pennsylvania, \\ ${ }^{3}$ Graduate Group in Demography, Population Studies Center, \\ University of Pennsylvania, Philadelphia, Pennsylvania, 19104, United States
}

\begin{abstract}
Problem statement: In a simple economic model, water scarcity arises as a result of an imbalance between the supply of and demand for water sources. Distribution in this setting is the source of numerous conflicts globally. Approach: Already, the Southwestern United States (US) suffers from annual drought and long-standing feud over natural water resources. Results: Population growth in the Southwestern United States along with the continued effects of climate change (natural and anthropogenic) predicts a perpetual decline in natural water sources, such as smaller snowpacks, in the coming years. As the increasing number of communities across multiple US states that subsist off of natural water supplies face water shortages with increasing severity, further water conflict will emerge. Such conflicts become especially protracted when the diversion of water from a source of benefit to one community negatively impacts nearby communities of humans and economically vital ecosystems (e.g., marshlands or tributaries). Conclusion/Recommendations: The ensuing politics and health effects of these diversions can be complicated and future water policies both domestically and internationally are lacking. To draw attention to and stimulate discussion around the lacking policy discussion domestically, herein we document existing and emerging consequences of watery scarcity in the Southwestern United States and briefly outline past and potential future policy responses.
\end{abstract}

Key words: Water scarcity, climate change

\section{INTRODUCTION}

There is limited literature and discussion on the public health effects of water scarcity in the United States (US). Perhaps this stems from a false notion that it is only the countries of the developing world that will contend with these and other consequences of anthropogenic and natural climate change (Food and Agriculture Organization of the United Nations, 2009). Such an assumption would be far from the truth. The wide-ranging public health effects of water stress are complex and somewhat unpredictable, beyond the basic tenet that they are never positive (Woodcock et al., 2009; Markandya et al., 2009; Friel et al., 2009; Smith et al., 2009; Wilkinson et al., 2009) and can have profound health and economic ramifications on local populations (Guzman, 2009; McMichael, 2002). With the Southwestern United States' growing populations dependent on limited natural water sources, the region's water situation and thus equitable distribution is increasingly challenged by demographic trends, such as heavy migration and attendant city growth to states like
New Mexico and Arizona (US Congress, 2007). This has led to exploitation of local ecosystems and a changing of the habitat to a degree where these adjacent states in particular will face more extreme and sustained droughts in the coming years, leading to thorny political and legal conflicts over distribution. Changes in local ecologies and/or water shortages could also result in diversion of water for one community that negatively impacts adjacent human populations and economically vital ecosystems (e.g., marshlands or tributaries) (Fisher and Acreman, 2004). To draw attention to the lacking policy discussion domestically, herein we briefly highlight examples of existing and emerging challenges around watery scarcity in the Southwestern United States and briefly outline past and potential future policy responses.

We begin with the Sierra Nevada mountain range which holds a snowpack that when melted, annually accounts for one third of California's drinking water and irrigation supply. As temperatures increase, this snowpack is predicted to melt faster and therefore not provide the steady stream of water in summer and fall

Corresponding Author: Amy C. Fuller, Department of Earth and Environmental Science, University of Pennsylvania, Philadelphia, Pennsylvania, 19104, United States 
that cities and farmers rely. In 2007 the snowpack had shrunk $10 \%$ below its wintertime average. Furthermore, rising temperatures have caused the Pacific Ocean to rise, risking salt water leaching into inland freshwater supplies (Young, 2007). In 2006 scientists at the US Department of the Interior simulated a breach in levees surrounding the Delta of central California. Saltwater intrusion from levee failure, which could be caused by rising sea levels or unstable ground due to subsidence, was projected to cause long-term cessation of water exports for months as breaches were repaired and saline water removed (Blach et al., 2006).

Over the years, the increased need for water has led the government of California to claim rights and divert water from remote areas. Take Owens Lake, which held water continuously for 800,000 years until 1913 when the Los Angeles Aqueduct began diverting water from Owens River at a point 51 miles above the Lake. By 1924 Owens Lake was dry. The remaining 60 square miles of salt flats caused dust to be generated from the dry lakebed, with dust storms traveling north and south through the Owens Valley (Libecap, 2007). The dust storms contain $\mathrm{PM}_{10}$ (McMichael, 2002), a particulate matter smaller than 10 microns which is easily diffused in the lower respiratory tract. Epidemiological studies of particulate air pollution have found that small increases in $\mathrm{PM}_{10}$ levels have been associated with increases in bronchitis, chronic cough and acute and chronic daily morbidity, as well as a decline in lung function (Reheis, 2006; McMichael, 2002; Pope et al., 1995). Community doctors near Owens Lake anecdotally report increased hospitalizations and emergency room visits during times of high $\mathrm{PM}_{10}$ concentration, especially among the elderly, individuals with heart or lung disease and children (McMichael, 2002).

Similar to the situation at Owens Lake, in 1941 the Los Angeles Department of Water and Power began diverting water from the Rush and Lee Vining streams feeding Mono Lake. This action caused a drop in the water level as well as an increase in the exposed flats that create dust storms and the threat of $\mathrm{PM}_{10}$ exposure (McMichael, 2002). The Mono Basin Environmental Impact (2003) also reports that lowered water levels decimated trout fisheries and increased salinity, threatening a population of brine shrimp. The lowered water level has already caused the disappearance of lagoons in the area, with estimations that the lagoondependent migratory duck population of Mono Lake has declined by $97 \%$ since the 1960 s.

These uncertain environmental domino effects contribute to the ongoing debate of how climate change and environmental degradation will affect public health (Horton, 2009). Consider the fact that to survive, all ecosystems depend on a natural balance of predators, prey and other resources. The Rush Creek bottomlands feeding Mono Lake for instance, hold many of the same characteristics as other wetlands in the US. Natural flooding carries the seeds of riparian vegetation, which after grown will provide habitat for bird populations that only migrate to the lake when algae and brine shrimp populations are plentiful. If any of these factors is changed, the delicate environmental balance will be disrupted, leaving poorer-quality wetlands. As such, the beneficial aspects of the wetlands-groundwater recharge and toxicant removal from agricultural run-off and sewage will become less productive.

Unfortunately, population movements to waterstressed areas have only exacerbated regional water problems. The US Congress (2007) found that the five metro areas with the largest numeric population increases between 2000 and 2006 were in the South and West, including Phoenix, Arizona and Riverside-San Bernardino-Ontario, California. Out of the 50 areas with highest numeric growth during that same time, 23 were located in the West. Phoenix-Mesa-Scottsdale, Arizona was also one of the ten fastest-growing metro areas by percentage at $24.2 \%$. Los Angeles was the second most populous metro area in July 2006 with 13 million people.

A stewing fight over limited water between Arizona's and California's growing cities began with the Colorado River Compact in 1922. The Colorado River is shared by seven states: Arizona, California, Colorado, Nevada, New Mexico, Utah and Wyoming. Though originally meant to avoid controversy, the Compact fails to appropriate water to the states individually because there was no agreement on equitable distribution. Instead, Herbert Hoover divided the states into Lower and Upper Basins, both of which could use 7,500,000 acre-feet of water per year (note: an acre-foot of water will cover an area of one acre to a depth of one foot). Arizona failed to ratify the Compact in part because the ratification of the Boulder Canyon Project Act in 1928 approved creation of the Hoover Dam. Believing that this facility would provide more water to California at Arizona's expense, Arizona went to court to argue that Congress lacked the power to take water away from the state. Arizona v. California reached the United States Supreme Court in 1931. The Court ended up respecting the Boulder Canyon Project Act by maintaining that Arizona and California should receive 2.8 and 4.4 million acre-feet of water from the main stem of the Colorado River, respectively.

The recent end to a long-standing legal feud provides a twist to this already complicated legal precedent. A suit between the US government and Gila 
River Pima Indian community in Arizona, one of California's partners in determining water distribution in the Colorado River Basin illustrates that challenges regarding water distribution and rights extend beyond the external habitat changes. The Pima community recently won a water settlement in 2008 and will be receiving 653,300 acre-feet of water along with $\$ 680$ million to rebuild water infrastructure from the US government (Archibold, 2008).

The Gila River Pima Indians originally survived Arizona's arid climate by creating a system of canals that diverted water for crop irrigation. In the late 18th and 19th centuries, Europeans began settling in the Upper Gila Valley and establishing farming communities. Combined with periodic droughts, the water diverted for these agricultural purposes began altering the natural course of the river and in time native farming systems dried up (McNamee, 1998). The resulting dietary impact transformed the traditional Pima diet of beans, squash, okra and other vegetables to government rations of white flour, canned meats and processed foods, leading to a community that the National Institutes of Health documents with "the highest prevalence and incidence of type 2 diabetes in the world" (National Institutes of Diabetes and Digestive and Kidney Diseases, 2009). Other notable titles include overweight rates as high as $80 \%$ for women and $67 \%$ for men as well as an incidence of kidney failure 20 times that of the general population (American Obesity Association, 2009). It was the loss of their original agrarian livelihood that led to their population health issues and thus the need for legal action to recover the water that may help the community return to its previous lifestyle.

\section{CONCLUSION}

These cases are in no way exhaustive examples of water scarcity and its complicated pernicious effects. Instead, they provide insight into issues potentially facing our collective future as water scarcity increases and communities negotiate for their rights to a water source. Most importantly, they outline the potential for negative consequences to occur when policy makers do not fully consider the ramifications of planned water diversions. These cases could easily occur in other regions of the US if future projects are not fully researched and all communities and ecosystems taken into account.

Yet, there are indeed some realistic policy answers. While they may not solve the issues at large, they represent substantial steps in the right direction. Policies could be enacted that require all new construction sites for residential and commercial buildings to include some type of rainwater technology. The Queensland Development Code in Australia, for example, requires that new construction of houses and townhouses meet water savings targets by using one or more conservation methods, such as installation of a rainwater tank. Agricultural and industrial processes need to be more efficient and research programs into related technologies better supported, both politically and financially. Work has been done with wastewater supply, drip and pivot irrigation systems and desalinization plants (Food and Agriculture Organization of the United Nations, 2009; Das and Kumar, 2009; Thompson et al., 2009; Survey USG, 2009). Also needed is research on improved water management (e.g., water banking) and drought-resistant crops (Godfray et al., 2010; Whittlesey and Huffaker, 1995).

In contrast to measuring, say, air or water quality near industrial areas, it has been relatively difficult to separate compounding factors and produce specific quantitative data that supports the analysis of the subtle and often latent impact of climate change on population (Fisher and Acreman, 2004). Consequently, the public has been slow to accept and respond to climate change warnings and governments worldwide have yet to form a global solution to halt environmental degradation. While the 2009 Copenhagen accord recognizes the scientific need for keeping temperature rises to a minimum it does not provide binding country-specific emission reduction goals (United Nations Framework Convention on Climate Change, 2009). If our national governments can't get it right, how can expect more from our state governments? That answer still remains unclear; what doesn't is the consequences of continued disregard and lack of acknowledgement of water stress in the Southwest and elsewhere in the US.

\section{ACKNOWLEDGEMENT}

$\mathrm{MOH}$ is supported by a training grant from the National Institute on Aging, United States National Institutes of Health (NIH) (T32 AG 000177-21). The authors alone are responsible for the views expressed in this publication and they do not necessarily represent the decisions, policy of views of the NIH.

\section{REFERENCES}

American Obesity Association, 2009. Obesity in Minority Populations.

http://obesity1.tempdomainname.com/subs/fastfact s/Obesity_Minority_Pop.shtml

Archibold, R.C., 2008. Indians' water rights give hope for better health. New York Times. http://www.nytimes.com/2008/08/31/us/31diabetes.html 
Blach, B., K. Jurist and S. Morton, 2006. Anticipating California levee failure: Government response strategy protecting natural resources from freshwater oil spills. Proceeding of the 6th Biennial 2006 Freshwater Spills Symposium in Portland, May 2-4, US EPA, pp: 1-18. http://www.epa.gov/oem/docs/oil/fss/fss06/port_2.pdf

Das, M. and A. Kumar, 2009. Effluent characterization and different modes of reuse in agriculture-a model case study. Environ. Sci. Pollut. Res. Int., 16: 466-447. DOI: $10.1007 / \mathrm{s} 11356-009-0102-\mathrm{z}$

Fisher, J. and M. Acreman, 2004. Wetland nutrient removal: A review of the evidence. Hydrol. Earth Syst. Sci., 8: 673-685. DOI: 10.5194/hess-8-6732004

Food and Agriculture Organization of the United Nations, 2009. Water Development and Management Unit Water Scarcity. http://www.fao.org/nr/water/issues/scarcity.html

Friel, S., A. Dangour, T. Garnett, K. Lock and Z. Chalabi, 2009. Public health benefits of strategies to reduce greenhouse-gas emissions: Food and agriculture. Lancet, 374: 2016-2025. DOI: 10.1016/S01406736(09)61753-0

Godfray, H., J. Beddington, I. Crute, L. Haddad and D. Lawrence, 2010. Food security: The challenge of feeding 9 billion people. Science, 327: 812-818. DOI: $10.1126 /$ science. 1185383

Guzman, J., 2009. Climate change and population growth. Lancet, 374: 450. DOI: 10.1016/S01406736(09)61449-5

Horton, R., 2009. The climate dividend. Lancet, 374: 1869-1870. DOI: 10.1016/S01406736(09)61994-2

Libecap, G., 2007. Owens valley Revisited: A Reassessment of the West's First Great Water Transfer. Standford University Press, ISBN: 10: 0804753792.

Markandya, A., B. Armstrong, S. Hales, A. Chiabai and P. Criqui, 2009. Public health benefits of strategies to reduce greenhouse-gas emissions: low-carbon electricity generation. Lancet, 374: 2006-2015. DOI: 10.1016/S0140-6736(09)61715-3

McMichael, A.J., 2002. Population, environment, disease and survival: past patterns, uncertain futures. Lancet, 359: 1145-1148. DOI: 10.1016/S0140-6736(02)08164-3

McNamee, G., 1998. Gila: The Life and Death of an American River. University of New Mexico Press, ISBN: 9780826318428, pp: 512.

Mono Basin Environmental Impact, 2003. Report for the Review of the Mono Basin Water Rights of the City of Los Angeles (Mono Basin EIR). http://www.monobasinresearch.org/onlinereports/ei rprofile.htm
National Institutes of Diabetes and Digestive and Kidney Diseases, 2009. Cross-Sectional and Longitudinal Studies of Pre-Diabetes in the Pima Indians. http://clinicaltrials.gov/ct2/show/NCT00340132.

Pope, C., D. Bates and M. Raizenne, 1995. Health effects of particulate air pollution: Time for reassessment? Environ. Health Perspect., 103: 472-480. PMCID: PMC1523269

Reheis, M., 2006. Dust deposition downwind of Owens (Dry) Lake, 1991-1994: Preliminary findings. J. Geophys. Res., 102: 25999-26008. DOI: 10.1029/97JD01967

Smith, K., H. Jerrett, R. Manderson, R.T., Burnett, V. Stone and R. Derwent, 2009. Public health benefits of strategies to reduce greenhouse-gas emissions: Health implications of short-lived greenhouse pollutants. Lancet, 374: 2091-2103. DOI: 10.1016/S0140-6736(09)61716-5

Survey USG, 2009. Thirsty? How 'bout a cool, refreshing cup of seawater. http://ga.water.usgs.gov/edu/drinkseawater.html

Thompson, T., H.C. Pang and L.I. Yu-Yi, 2009. The potential contribution of subsurface drip irrigation to water-saving agriculture in the western USA. Agric. Sci. China, 8: 850-854. DOI: 10.1016/S1671-2927(08)60287-4

US Congress, 2007. US 50 Fastest-Growing Metro Areas Concentrated in West and South. US Census Bureau News. http://www.prnewswire.com/newsreleases/50-fastest-growing-metro-areasconcentrated-in-west-and-south-57891592.html

United Nations Framework Convention on Climate Change, 2009. Draft decision -/CP.15: Copenhagen Accord. Drafted at the 15th session of the United Nations Framework Convention on Climate Change, Copenhagen, pp: 7-18.

Whittlesey, N. and R. Huffaker, 1995. Water policy issues for the twenty-first century. Am. J. Agric. Econ., 77: 1199-1203. DOI: 10.2307/1243347

Wilkinson, P., K. Smith, M. Davies, H. Adair and B.G. Armstrong, 2009. Public health benefits of strategies to reduce greenhouse-gas emissions: household energy. Lancet, 374: 1917-1929. DOI: 10.1016/S0140-6736(09)61713-X

Woodcock, J., P. Edwards, C. Tonne, B.G. Armstrong and O. Ashiru, 2009. Public health benefits of strategies to reduce greenhouse-gas emissions: urban land transport. Lancet, 374: 1930-1943. DOI: 10.1016/S0140-6736(09)61714-1

Young, S., 2007. In California, Warming Trend Renews Water Debate. North County Times. http://blogs.lib.berkeley.edu/wrca.php/2007/04/09/i n_california_warming_trend_renews_water 